\title{
Assessment of Urban Sustainable Development: Example of Rezekne City
}

\author{
Lienīte Litavniece \\ Rezekne Higher Education Institution
}

\begin{abstract}
Since $90 \mathrm{~s}$ of the $20^{\text {th }}$ century sustainable development has become a global issue which is receiving increasing attention. Successful sustainable development is only possible from the bottom to the top, which means that the human and environmental mutual relations must be taken into account not only on a global scale as a whole, but also focus on the much smaller territorial units.

The role of the city as the administrative territorial unit has significantly increased in recent years, the acknowledgment for that can be found in the European Union Cohesion Policy, polycentric development policy, spatial planning policy, etc., in the figures of the rapid population growth in urban areas, about joining of separate scientific disciplines in order to study current issues in the cities.

In sustainable development studies special attention is paid to mega cities or capitals, which have the most significant impact on the environment, based on certain key indicators - $\mathrm{CO} 2$ emissions, the amount of municipal solid waste generated in cities, etc.

The planning documents, that provide a picture of the specific urban sustainable development priorities, play an important role in ensuring sustainable development.

The aim of the article is to explore the sustainable development strategies of the city of Rezekne for 2013-2030 in conformity with the five dimensions of sustainable development and to assess the development possibilities of Rezekne.

During the study the sustainable development strategy of Rezekne for 2013-2030 was evaluated, strategic aims, long-term priorities, and actions were established. As a result, it was concluded that they meet all five dimensions of sustainable development, but in the strategy for these actions, it is necessary to focus on the essence of the concept of sustainable development, that meets the needs of the present without compromising the ability of future generations to meet their own needs [1].

The evaluation of current performance shows that the strategy of planned targets may not materialize and as a result have a significant impact on sustainable development, so it is necessary to make appropriate adjustments in the operational plans.
\end{abstract}

Keywords: city, dimensions, planning documents, sustainable development.

\section{INTRODUCTION}

The importance of sustainable development is growing in a fast-paced era of globalization, which is reflected in the solution of urgent global problems (global warming, deforestation, etc.) using different levels of planning documents. In the European Union and its Member States, the sustainable development strategy has been developed at all levels: at the level of the European Union, national, regional and / or local level. It is important that each lower-level document is hierarchically subordinated to a higher level document. This creates confidence in the progress towards common strategic objectives.

Sustainable development is often associated with the environmental problems, although in essence it is a diverse set of aspects, including socio-economic, political, cultural, etc. issues. It was necessary to develop a sustainable development strategy for 2013 2030 at Latvian national, regional and local levels.
Getting acquainted with the Regional Development and Local Government Ministry developed "Methodological recommendations for the sustainable development strategies and development program for the regional and local levels" (23.09.2010) [2] should be concluded that the concept of "sustainable development" is mentioned in this document, but its explanation is not given.

Sustainable development is one of the concepts that are integrated into the European Union's planning and policy documents (e.g. "Europa2020"), thus emphasizing its importance. For the first time the concept of sustainable development was mentioned at the United Nations Conference on man-made environment (in 1972) [3]. In the following years, it was highlighted in various reports and statements: in Brandt Commission's report "North-South: A Programme for Survival" (1980), in Gro Harlem Brundtland Commission's report "Our Common Future" (1987) [3], in the Rio Declaration on 
Environment and Development and the Action Plan for the 21st Century (Agenda 21) (1992) [3], in Rio + Conference Declaration "The future we want" (2012) [3].

Sustainable development is the latest manifestation of a centuries-old ethics related to human and environmental relations and the present generation responsibility towards future generations [4].

Sustainable development meets the needs of this generation without compromising future generations to meet theirs. (..) It promotes a dynamic economy with full employment, a high level of education, good health care, social and territorial cohesion and environmental protection in a peaceful and secure world, respecting cultural diversity [ 5]."

The definition also states that sustainable development is not only related to ecological issues, but there is much more to be analyzed.

Canadian International Development Agency's evaluation of sustainable development states that it is necessary to take into account three aspects: economic, environmental and social. Each of the aspects is analyzed based on certain indicators. Economy: unemployment rate, job, economic growth. Environment: green spaces, energy efficiency, water quality / availability, air quality, waste, mobility. Social: compact city, housing, quality public spaces, education, sanitation, health [6]. Each of these indicators is analyzed in accordance with sustainable development. This model is more appropriate to assess the situation in the field of sustainable development, but it does not take attention to conditions that may substantially affect sustainable development.

Allen explains the sustainable development as a five-dimensional model: economic sustainability, social sustainability, ecological sustainability, the sustainability of the built environment, and political sustainability. After analyzing the essence of each aspect, it is concluded that the productive use of sustainable development resources brings long term benefits, secures the certain standard of living using natural, physical and economic capital, respects cultural heritage and cultural diversity, taking into account the interaction between the state and the use of environmental resources, buildings and infrastructure do not damage and erode the environment. Political sustainability, which is regulating the other four dimensions involved in the relationship, is unifying in this model [7].

S.K. Cheng, Q.W. Min and L.F. Li [8] in the analysis of sustainable development use a fourdimensional model: economic dimension, ecological dimension, environmental dimension, and multidimensions. Analyzing sustainable development by the model proposed by the authors, the above mentioned information should be taken into account.

E.Römpczyk [4] explains sustainable development as the five dimensions - a strong economic development, cultural diversity, biological diversity, equal opportunities for all, democratic relations between the state and society [4] - the interaction between time and space. This shows that the analysis of the sustainable development must be based on a long-term process of research, because only then obtained results and the corresponding conclusions will be objective.

Therefore, the article aims to explore the compliance of sustainable development strategy of Rezekne for 2013-2030 with the five dimensions of sustainable development and to assess the development possibilities of Rezekne.

To achieve this goal, the following tasks were set:

- Explore the theoretical aspects of concept of "sustainable development";

- To assess the compliance the sustainable development strategy of Rezekne city for 2013 - 2030 with five dimensions of sustainable development;

- To estimate just a few performance indicators mentioned in the strategies because of a limited size of the article

\section{MATERIALS AND METHODS}

Data analysis techniques used in the research: logical constructive method, monographic method.

Data collection methods used in the research: document analysis method.

Data were analysed using the SPSS program.

Practical research base: Sustainable development strategy of Rezekne for 2013 -2030, statistical analysis of the data for the period from 2010 to 2014 .

Rezekne sustainable development strategy for 2013-2030 (hereinafter - the strategy) is used as a base for the research. The strategy is one of the most important planning documents that reflect the city's long-term development plans in accordance with sustainable development.

This document sets out four strategic objectives of Rezekne each of which corresponds to one of the long-term priorities: "Rezekne - internationally competitive economic development centre", "Rezekne - creativity, Latgalian, cultural tourism and leisure centre", "Rezekne - education, research and sports development centre "," Rezekne - human and environment-friendly, safe and modern city " with a number of actions. The author carried out a content evaluation of each action mentioned in the strategy in order to determine the overall compliance with sustainable development. Each of the actions was evaluated according to five dimensions, answering a question with a "yes" or "no."

\section{RESULTS AND DISCUSSION}

Based on the theoretical literature studies, the author in her study will use a five-dimensional model: 
economic, social, environmental, and political (institutional), cultural and cultural history.

Economic Sustainability means economic growth, respecting sustainable development.

Environment sustainability means environmentally friendly buildings and infrastructure, green areas in the city, ecological issues, taking into account sustainable development.

Social Sustainability means people's quality of life, in a criminal case (security issues), education and health systems availability and quality, situation in social housing, sanitation and hygiene situation, infrastructures and the quality of the parks in accordance with sustainable development.

Political (institutional) sustainability is characterized by democratic relationship between specific users of the area (municipality, investor citizenships, different groups of community etc.) in accordance with sustainable development.

Cultural and cultural history sustainability is the basis for the previous four dimensions. This aspect determines what the sustainable development will be, taking into account the past, the situation today and future visions.

Rezekne sustainable development strategy for 2013-2030 (hereinafter - the strategy) is used as a base for the research. The strategy is one of the most important planning documents that reflect the city's long-term development plans in accordance with sustainable development.

This document sets out four strategic objectives of Rezekne each of which corresponds to one of the long-term priorities: "Rezekne - internationally competitive economic development centre", "Rezekne - creativity, Latgalian, cultural tourism and leisure centre", "Rezekne - education, research and sports development centre "," Rezekne - human and environment-friendly, safe and modern city " with a number of actions. The author carried out a content evaluation of each action mentioned in the strategy in order to determine the overall compliance with sustainable development. Each of the actions was evaluated according to five dimensions, answering a question with a "yes" or "no." As a result, it was determined that in total the planned actions correspond to all five dimensions of sustainable development (Table 1), but there is a different percentage distribution.

TABLE 1

LONG-TERM PRIORITIES DEFINED IN THE MAIN ACTION IN ACCORDANCE WITH DIMENSIONS, \% [12]

\begin{tabular}{|l|l|l|}
\hline Dimensions & No & Yes \\
\hline Economical & 60,9 & 39,1 \\
\hline Environment & 68,8 & 31,3 \\
\hline Social & 46,9 & 53,1 \\
\hline Cultural and cultural history & 81,3 & 18,8 \\
\hline Political (institutional) & 70,3 & 29,7 \\
\hline
\end{tabular}

Most of the planned activities (53.1\%) relate to the social dimension, but smallest number to the cultural and cultural history dimension $(18.8 \%)$. The action assessment of strategy shows that the largest number of activities is aimed to solving social problems, as well as priorities, that are specific to social dimension, are identified. Cultural and cultural dimension history is the basis for sustainable development, because it provides development options and directions for other dimensions, but it is not a primary one compared to other dimensions.

It is necessary to evaluate strategies not only after the certain deadline, but also to make an interassessment in order to draw appropriate conclusions about the feasibility of the planned objectives.

Due to the wordage limit the author carried out analysis only of the most important indicators that describe sustainable development.

It is planned in the strategy that the population of the town of Rezekne will grow to 32,000 till 2020, while in 2030 to 35000 inhabitants (Fig.1.). However, assessing the dynamics, it is concluded that since 2012 the population has declined by $6 \%$, and currently has less than the planned 32000 inhabitants in 2020 .

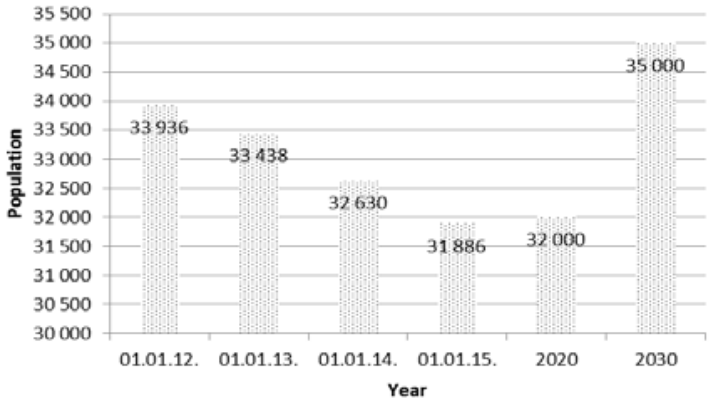

Fig. 1. Population of Rezekne in 2012-2030 [9]

The natural growth rate and net migration significantly affect the number of population.

It is planned in the strategy that by 2020 there won't have been a negative tendency in natural increase, but already by 2030 this figure will have changed to positive (Fig.2.).

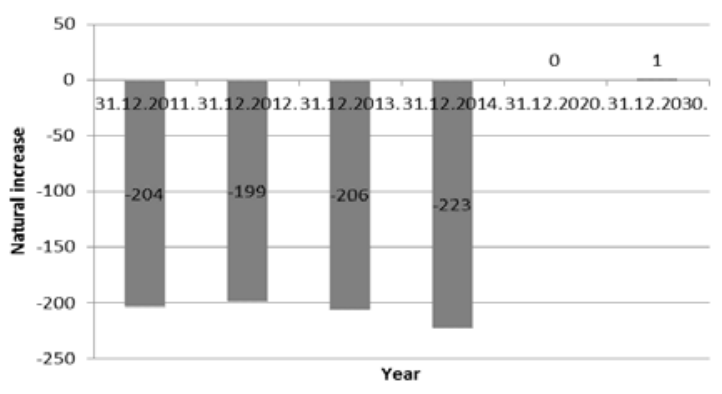

Fig. 2. The natural growth of population in Rezekne in 2011 -2030 [9]

However, statistics show that since 2011 dynamics in the natural growth has remained negative, which 
means that it would be difficult to achieve planned indicators in this area of the strategy.

It is planned in the strategy that by 2020 the negative trend of net migration will have been stopped, but already by 2030 this figure will have had a positive trend. The current figures show that during the analyzed period this figure varies each year (Fig.3.). In 2011 it increased by $10.9 \%$ compared with 2010 , but in 2012 decreased by $49.88 \%$ compared with the previous year, but in 2013 there was again an increase of $29.73 \%$, compared with 2012 . But despite annual fluctuations, in 2013 compared with 2010 net migration decreased by $19.95 \%$, which means that, in theory, by 2020 it is possible to achieve strategic objectives.

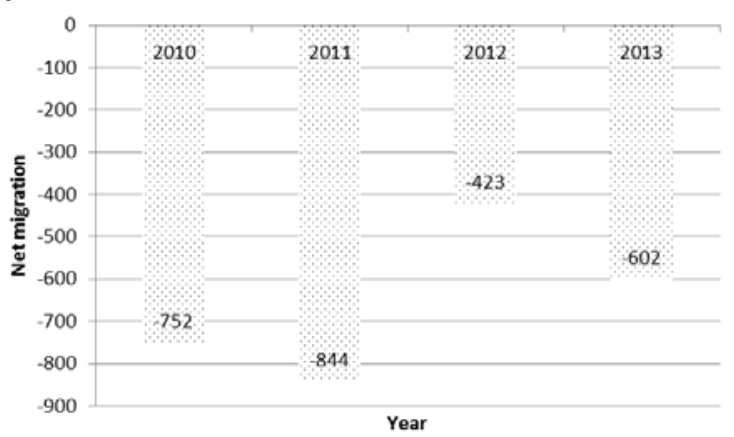

Fig. 3. Net migration in Rezekne in 2010-2013. [9]

It is planned that by 2030 the economically active number of units of the market sector will have increased. Analysis of available statistical information shows that the number of units of the economically active sector of the market in 2013 increased by $6.77 \%$ (fig.4.) And generally positive dynamics is seen.

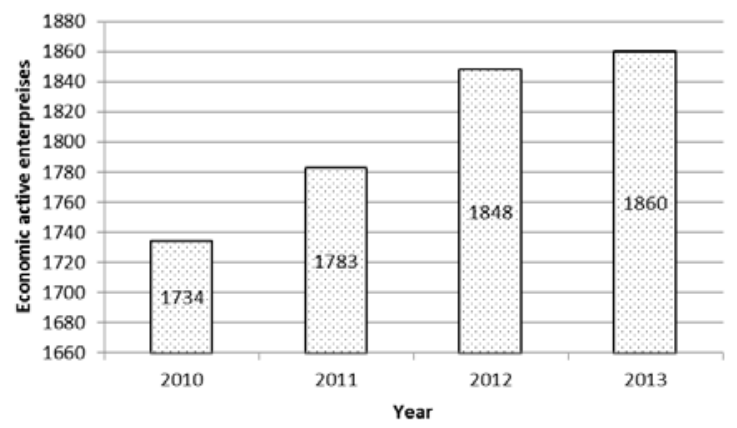

Fig. 4. Economically active units of market sector in Rezekne in 2010 - 2013 [9]

Business development is the basis for a favourable socio-economic situation, however, for the full evaluation of this issue it is necessary to analyze units of the economically active market sector by size and business forms.
TABLE 2

ECONOMICALLY ACTIVE UNITS OF MARKET SECTOR IN REZEKNE AFTER THE FORM OF ENTREPRENEURSHIP IN $2010-2013$ [9]

\begin{tabular}{|l|l|l|l|l|}
\hline Form of business & 2010 & 2011 & 2012 & 2013 \\
\hline Self-employed people & 775 & 799 & 830 & 825 \\
\hline Sole proprietorships & 184 & 183 & 173 & 179 \\
\hline Commercial companies & 760 & 787 & 834 & 844 \\
\hline Farms and fisheries & 15 & 14 & 11 & 12 \\
\hline
\end{tabular}

The dominant form of business in Rezekne is a self-employed person and a commercial society in which more than 800 companies are involved (Table 2 ). The number of self-employed people during the analyzed period has grown by about $6 \%$ in 2013 compared with 2010, but compared with the year 2012 has decreased by $0.6 \%$. This reduction is due to changes in legislation, as since 2014 changes to the personal income tax entered into force, which provided a minimum fee of 50 EUR in cases if one is registered as a self-employed person, but economic activity is not implemented.

From a city development point of view it should be admitted that the interest and the desire of people to become entrepreneurs have serious grounds for longterm development. With increasing number of companies, the appropriate positive trends should be monitored for the unemployment rate.

Historically, many large companies operated in Rezekne, where the number of employees was several hundred or even in some exceeded 1,000. Disruption of large enterprises contributed to the strong increase of unemployment level in the city.

Despite the fact that continually new businesses start up, rapid decrease of the unemployment rate does not occur. Around 91\% of enterprises in Rezekne are micro- enterprises, but rather only $0.1 \%$ of enterprises are large companies (Table 3). According to the European Commission Regulation No.800 / 2008 [10], micro enterprises are those with fewer than 10 employees and a turnover or balance sheet of those does not exceed 2 million EUR. In order to significantly reduce the unemployment rate in Rezekne a much faster increase of economically active market sector units in the micro or small business category or at least a start-up of one large company is necessary.

TABLE 3

UNITS OF ECONOMICALLY ACTIVE MARKET SECTOR IN REZEKNE AFTER SIZE IN 2010 - 2013 [9]

\begin{tabular}{|l|l|l|l|l|}
\hline The size of the group & 2010 & 2011 & 2012 & 2013 \\
\hline Micro & 1568 & 1618 & 1683 & 1698 \\
\hline Small & 145 & 143 & 138 & 137 \\
\hline Average & 19 & 20 & 25 & 25 \\
\hline Large & 2 & 2 & 2 & 2 \\
\hline
\end{tabular}

It should be taken into account that a start-up of a large manufacturing business is unlikely probability, as the automation of the production process requires a minimum number of employees. 
As a result, unemployment in Rezekne is still an urgent and important problem, which significantly affects the socio-economic situation and threats to long-term strategic objectives. Figures show that in 2012, compared with 2011, the unemployment rate rose by $1.9 \%$, but since 2012 , the unemployment rate decreased by $4.6 \%$ (Fig.5.), which affects not only the growth of economic active market sector units, but also the overall population decrease in Rezekne.

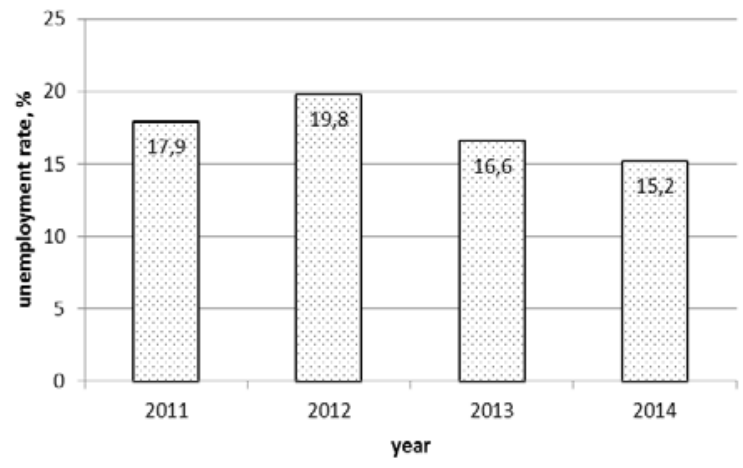

Fig. 5. The unemployment rate in Rezekne in 2011-2014 [9]

The socio-economic situation in the city is characterized not only by unemployment, but also by the security level.

Number of criminal offenses registered in Rezekne is variable (Table 4). In 2012, the registered criminal offenses decreased by almost $25 \%$ compared with 2011 , but in 2013 increased by approximately $10 \%$ compared with 2012. In 2014 number increased by $6 \%$ compared with 2013. Analyzing the number of offenses per 10000 inhabitants, it is concluded that the increase is faster (by $12.4 \%$ in 2013 compared with 2012. In 2014 number increased by $6.3 \%$ compared with 2013. The overall trend shows a decrease of security level in Rezekne. According to the author, this situation is also partly affected by the elimination of Rezekne municipal police in 2014.

TABLE 4

NUMBER OF CRIMINAL OFFENSES IN REZEKNE IN $2010-2014$

\begin{tabular}{|c|c|c|}
\hline Year & \begin{tabular}{lr}
\multicolumn{2}{l}{ Registered number } \\
of & criminal \\
offenses & in \\
Rezekne & \\
\end{tabular} & 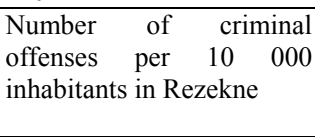 \\
\hline 2010 & 867 & 249 \\
\hline 2011 & 907 & 283 \\
\hline 2012 & 685 & 220 \\
\hline 2013 & 762 & 251 \\
\hline 2014 & 811 & 268 \\
\hline
\end{tabular}

Environmental dimension characterize ecological issues like waste management, water and air quality. Rezekne city implemented projects (for example, to improve the quality of drinking water. Waste management, etc.) indicates the municipal interest in ensuring a sustainable environment.

\section{CONCLUSIONS}

In the strategy of the city of Rezekne five dimensional model of sustainable development is taken into account, as the planned actions are focused on the solving of the economic, social, environmental, cultural, and political issues. However, the author believes that in the strategic objectives, priorities and long-term actions there is a lack of emphasis on the concept of "sustainable development" essence. For example, keep to the principles of sustainable development in the construction of new buildings or arrangement of brown field sites.

Strategy and statistical analysis of information about the city of Rezekne provides answers for the realization of the planned performance indicators. It must be concluded that there are greatest doubts concerning the demographic execution because the current dynamics show negative trends. Decrease in the number of population shows socio-economic problems in the city. The high unemployment rate contributes to population migration; it negatively affects the rate of natural growth and safety in the city.

According to the author, it is necessary to activate the political (institutional) dimension, in order to promote entrepreneurship and activate tourists' interest in the city with the help of municipal disposal instruments (projects, tax credits, etc.).

\section{REFERENCES}

[1] World Commission on Environment and Development ('Brundtland Commission') Our Common Future. Oxford: Oxford University Press, 1987, pp.43

[2] Reǵionālās attīstības un pašvaldību lietu ministrijas ,Metodiskie ieteikumi ilgtspējīgās attīstības stratēgiju un attīstības programmu izstrādei reǵionālā un vietējā lìmen $\vec{\imath}$ 2010.gada 23.septembris

[3] G.Brūmelis „Vides likumdošana”, 2014.gada augusts. [Online]. Available: http://latvijas.daba.lv/aizsardziba/likumdosana/ [Accessed: Nov. 10, 2014].

[4] E.Rompczyk, Gribam ilgtspējīgu attīstību. R.: Friedrich- Ebert - Schiftung, 2007, 152 lpp.

[5] Eiropas Savienības Padome „ES ilgtspējīgās attīstības stratēgija" 2006.g.6.oktobris

[6] Canadian International Development Agency. „Indicators for sustainability. How cities are monitoring and evaluating their success", November, 2012. [Online]. Available: file://C:/Users/Lienite/Downloads/indicators\%20for\%20sustai nability-intl\%20case \%20studies-final\%20(1).pdf [Accessed: Nov. 30, 2014].

[7] A.Allen , „Sustainable cities or sustainable urbanisation?, UCL's Journal of sustainable cities, Summer 2009. [Perspective]. Available: http://www.ucl.ac.uk/sustainablecities/results/gcsc-reports/allen.pdf . [Accessed Dec. 12, 2014].

[8] S.K. Cheng, Q.W.Min and L.F.Li, ,Research and Theories in Sustainable Development in China," AREA STUDIES CHINA: REGIONAL SUSTAINABLE DEVELOPMENT REVIEW Vo 1 . I I I. [Online]. Available: http:/www.eolss.net/ sample-chapters/c16/e1-54-44.pdf. [Accessed Dec. 12, 2014].

[9] Rēzeknes pilsētas mājas lapa. [Online]. Available: http://www.rezekne.lv/skaitli-un-fakti/. [Accessed: Feb.5, 2015].

[10] Eiropas Komisijas regula Nr.800/2008, kas atzīst noteiktas atbalsta kategorijas par saderīgām ar kopējo tirgu, piemērojot Līguma 87. un 88.pantu (vispārējā grupu atbrīvojuma regula) 
Lienīte Litavniece / Environment. Technology. Resources, (2015), Volume II, 168-173

2008.gada 6.augusts. [Online]. Available: http://eurlex.europa.eu/LexUriServ/LexUriServ.do?uri=CONS LEG:2008R0800:20131201:LV:PDF. Accessed: Feb. 16, 2015].
[11] Rēzeknes pilsētas ilgtspējīgās attīstības stratēǵija 2013.2030.gadam. [Online]. Available: http://www.rezekne.lv/ uploads/media/REZEKNE_IAS_2030.pdf . [Accessed: Feb. 10, 2015]. 